\title{
STABILITY COMPARISON OF 9 MODERN PLACED BLOCK REVETMENT TYPES FOR SLOPE PROTECTIONS
}

\author{
Mark Klein Breteler ${ }^{1}$, Yvo Provoost ${ }^{2}$, Paul van $\mathrm{Steeg}^{1}$, Guido Wolters ${ }^{1}$, Dorothea Kaste ${ }^{1}$ and \\ Gijsbert Mourik ${ }^{1}$
}

\begin{abstract}
Placed block revetments are constructed to withstand the wave forces on dikes, especially in regions where rip rap is not locally available, such as the Netherlands. The blocks are placed adjacent to each other on a filter layer to form a relatively closed and smooth surface, which is easy to walk on. Large-scale test in the Delta Flume of Deltares have been carried out to compare the stability of nine types of block revetments, presently on the market in the Netherlands (Klein Breteler, 2016). All tests have been performed with a comparable test setup and test program. The test program consisted of three series of tests. The first two series were short duration tests of 1000 waves with two different wave steepnesses, in which the wave height was increased step-by-step until damage occurred. The third test series was a long duration test lasting for 26 hours, or until damage occurred. The results of the tests have been used to quantify a correction factor in the calculation method. This correction factor, or stability factor, makes that the calculation method gives the same results as the Delta Flume tests, taking a safety margin into account. In this way the type-specific stability of each type of block revetment was better included in the calculation method.
\end{abstract}

Keywords: Block revetment, levee, wave attack, stability, physical model, Delta Flume

\section{INTRODUCTION}

A placed block revetment is a special type of slope protection consisting of a regular pattern of (concrete) blocks, forming a relatively smooth surface. It gives a nice looking sea defence at which the public can easily access the waterline and which provides a high stability under wave attack. This type of slope protection is frequently used in the Netherlands and abroad.

The various manufacturers of block revetments in the Netherlands have a wide variety of types of block revetments. Up to now, the calculation method for the design of block revetments could not distinguish the specific stability of each of these types of block revetments. Most of them were in one single category, suggesting that those had the same stability.

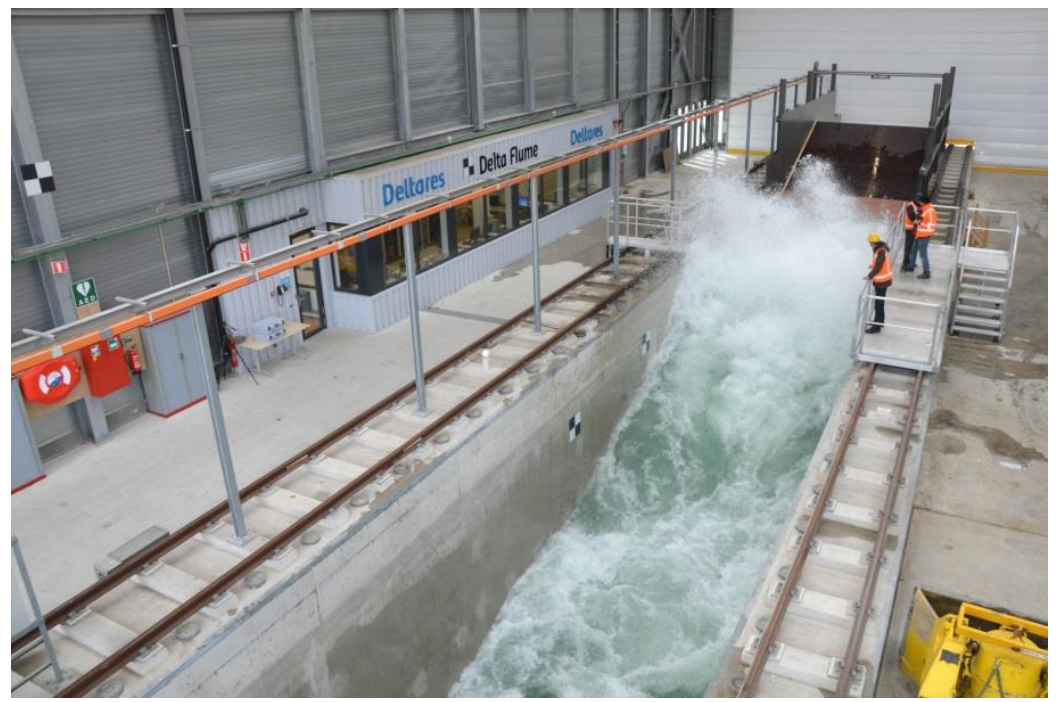

Figure 1, Wave attack on a slope with block revetment in the Delta Flume

To better include the type-specific stability of the present-day block revetments in the calculation method, a large project was initiated by the Dutch Ministry of Infrastructure and Water with the objective to measure the stability of these block revetments (Klein Breteler, 2016). All manufacturers were invited to participate in this project, which was financed for $80 \%$ by the Dutch Ministry and the rest by the manufacturers.

\footnotetext{
${ }^{1}$ Deltares, P.O.Box 177, 2600 MH Delft, the Netherlands, mark.kleinbreteler@deltares.nl

${ }^{2}$ Ministry of Infrastructure and Water Division, Rijkswaterstaat, P.O. box 50144330 KA Middelburg, the Netherlands
} 
Conflicting scale rules make it impossible to investigate this in a small scale model. The wave motion is governed by the Froude scaling, while the flow in the granular layer under the blocks and the pressure difference across the cover layer are governed by the Reynolds scale. The pressure difference across the cover layer, for which the flow in the filter is very important, is the primary load that induces instability. This means that the stability can not be investigated on small-scale.

The procedure to test the stability of a new type of revetment, before it is allowed to be applied on a primary sea defence in the Netherlands, is described in the Dutch standard NEN7024.

\section{TESTED REVETMENT TYPES}

Nine types of block revetments from five manufacturers have been tested in this project in the period from December 2013 up to July 2015, listed in Table 1. The revetments are shown in Figure 2 to 8.

\begin{tabular}{|c|c|}
\hline Manufacturer & Block revetment type \\
\hline \multirow[t]{2}{*}{ Holcim Coastal BV } & Basalton \\
\hline & Basalton+ \\
\hline \multirow{2}{*}{ Hillblock BV } & Hillblock $^{\circledR}$ (Slim and Basis) \\
\hline & Testblok \\
\hline \multirow[t]{2}{*}{ Altena Infra-materialen BV } & RONA ${ }^{\mathbb{B}}$ ton \\
\hline & RONA ${ }^{(3)}$ Taille \\
\hline \multirow{3}{*}{$\begin{array}{l}\text { LBN Betonproducten BV / Berding } \\
\text { Beton GmbH }\end{array}$} & Verkalit $^{(B)} \mathrm{mgv}$ \\
\hline & Verkalit $^{\left.()^{2}\right)}$ GOR \\
\hline & C-Star \\
\hline
\end{tabular}

Table 1, Tested revetment types
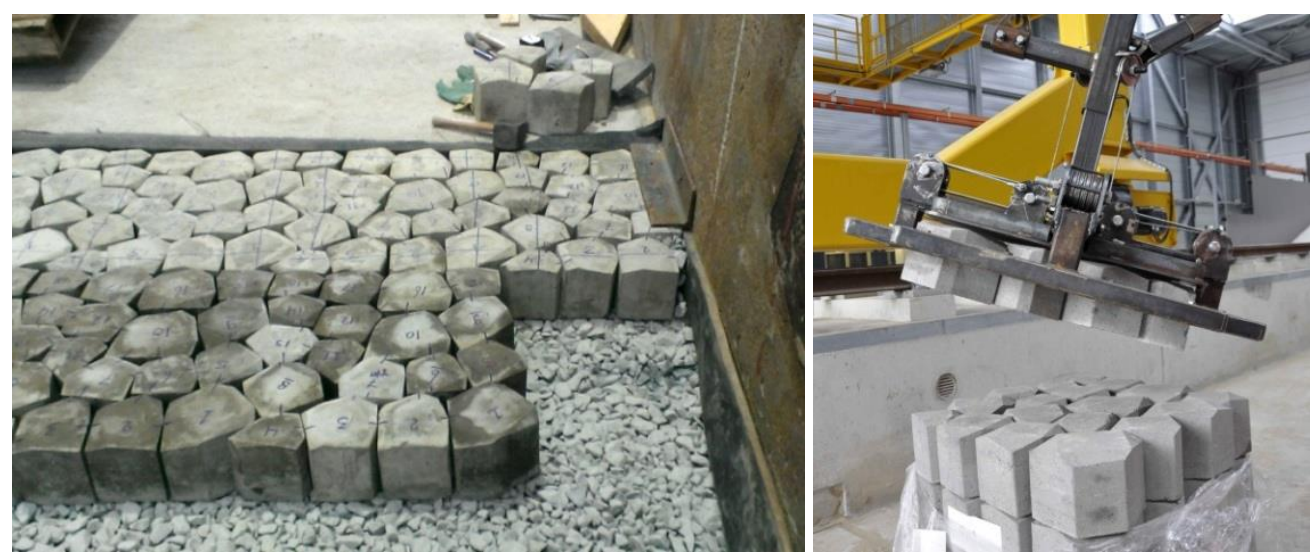

Figure 2, Basalton and Basalton+
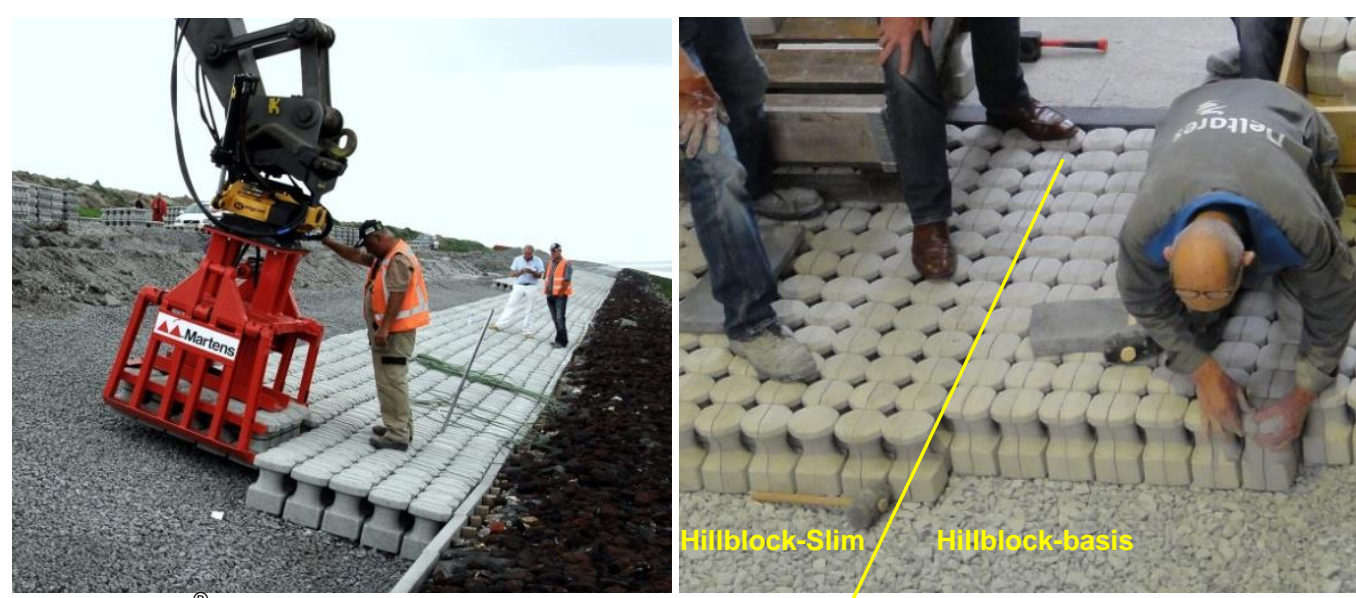

Figure 3, Hillblock ${ }^{\circledR}$ (Testblok looks similar) 

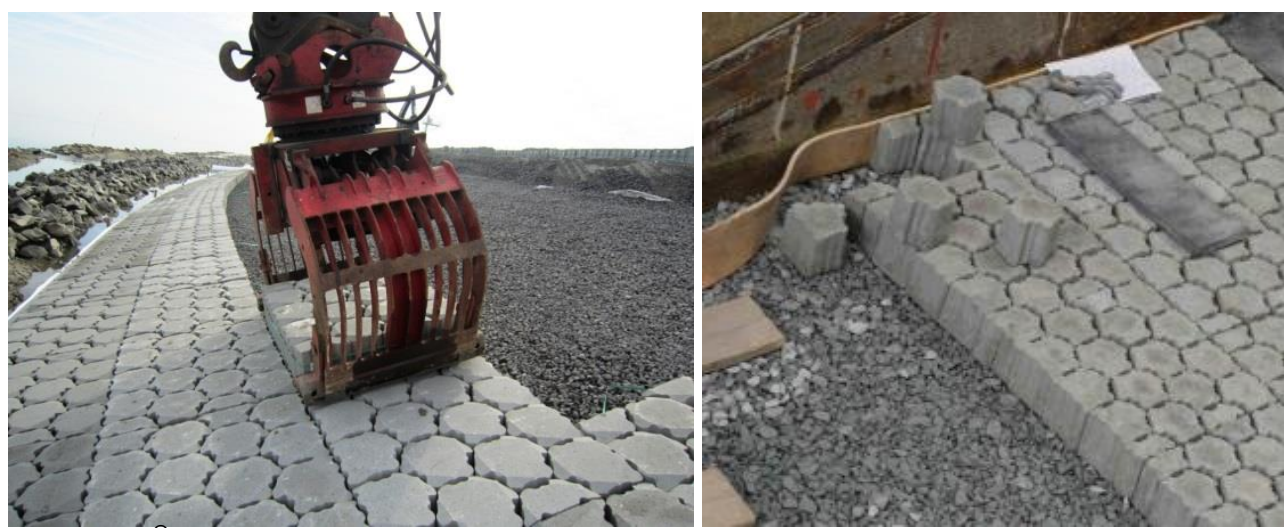

Figure 4, RONA ${ }^{\circledR}$ ton
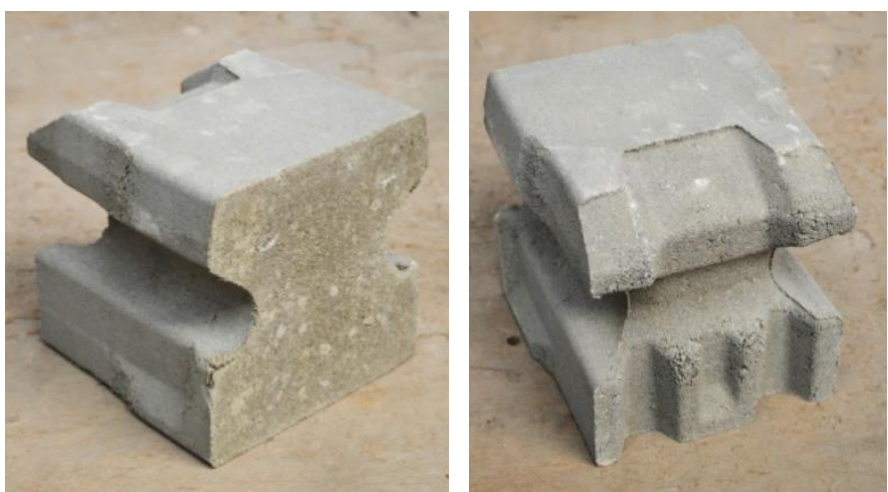

Figure 5, RONA ${ }^{\circledR}$ Taille
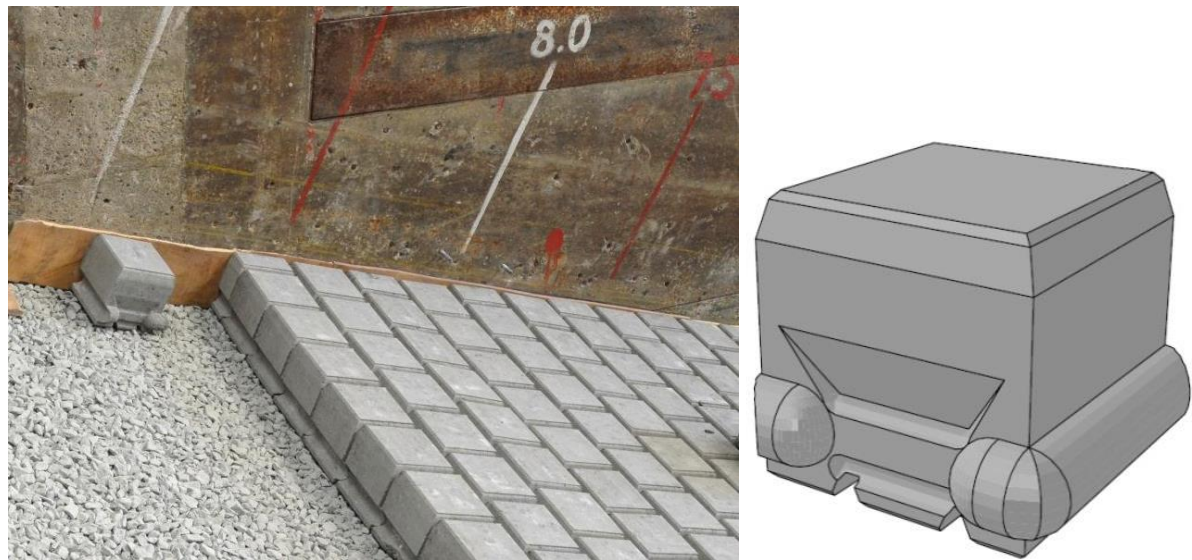

Figure 6, Verkalit $^{\circledR}$ mgv

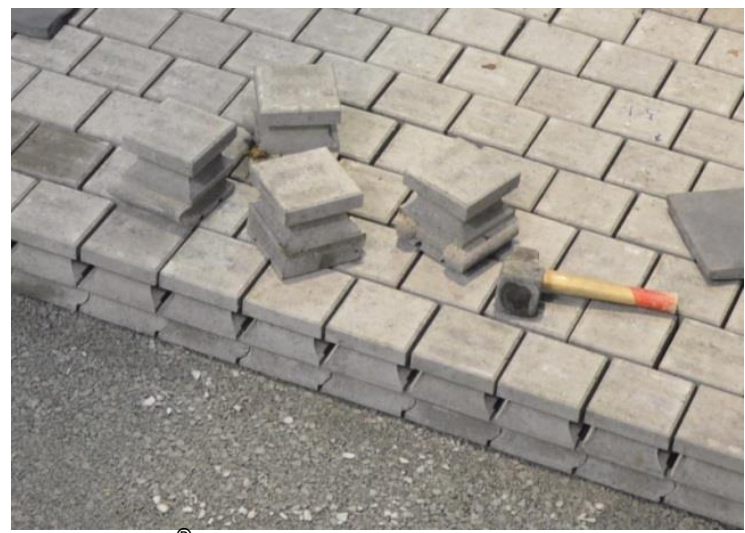

Figure 7, Verkalit $^{\circledR}$ GOR

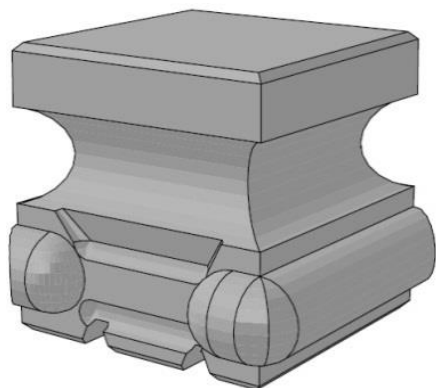



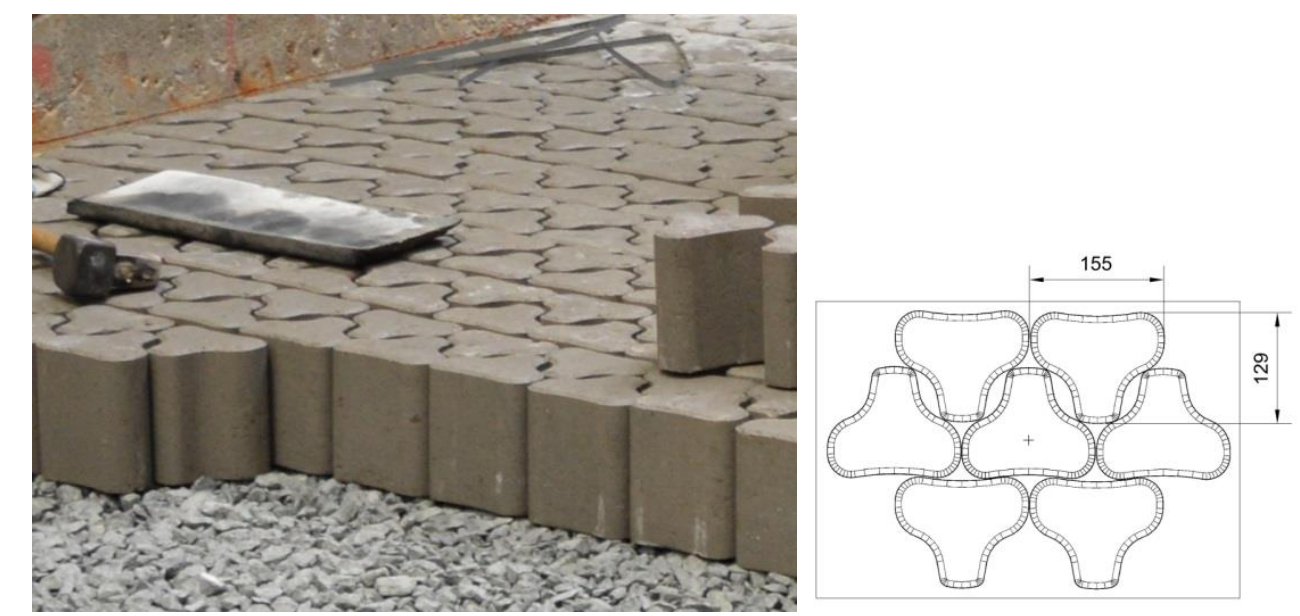

Figure 8, C-Star
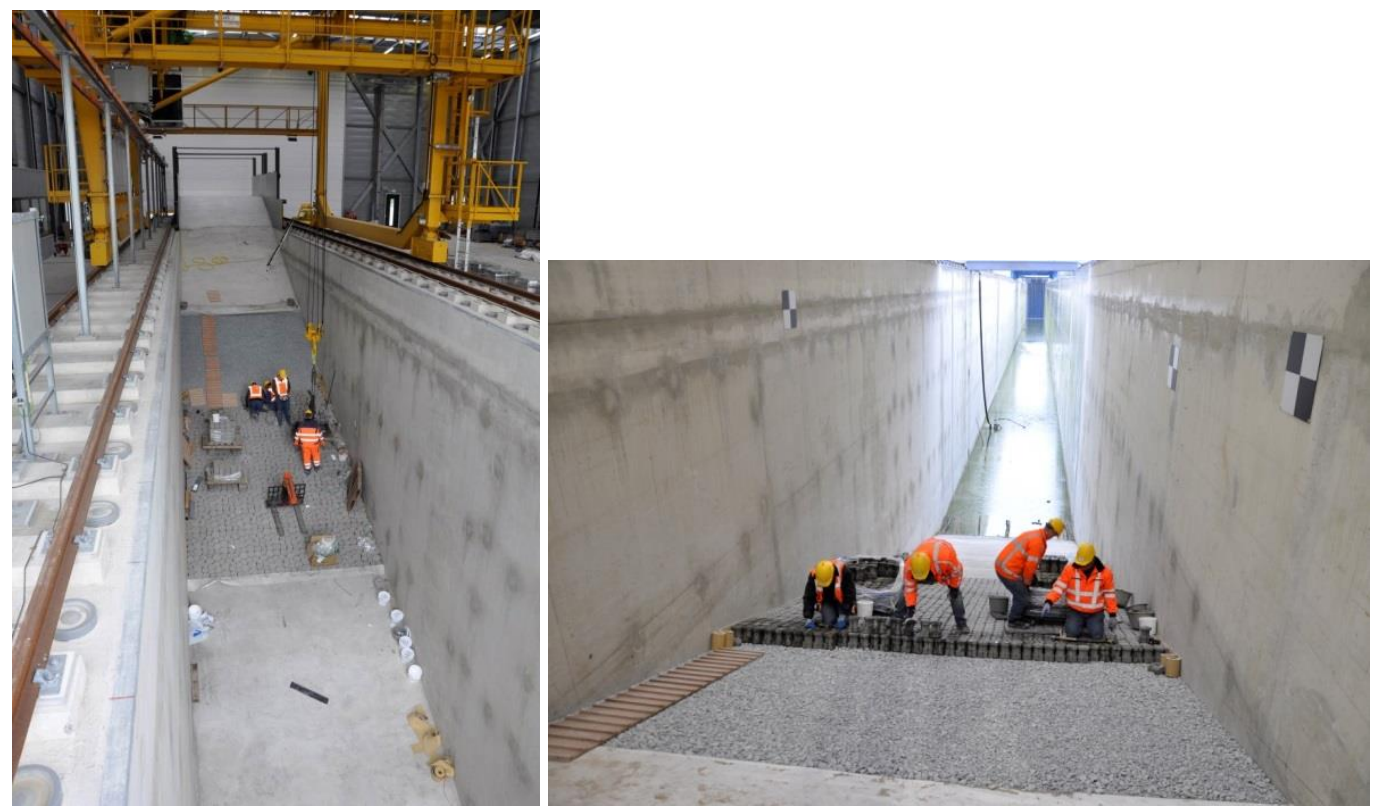

Figure 9, Block revetment placement in the Delta Flume of Deltares

Also wave run-up tests have been carried out for some revetments (Van Steeg et al 2016), namely Hillblock $^{\circledR}$, RONA ${ }^{\circledR}$ Taille and Verkalit ${ }^{\circledR}$ GOR. For these types of block revetments a run-up reduction effect was expected due to the shape of the blocks.

\section{THEORY}

The stability of block revetments is governed by the hydraulic load (pressure difference across the cover layer), the weight of the blocks and the interaction between the blocks. The stability factor is mainly a quantification of the interaction between the blocks and is therefore not the only characteristic of the revetment that governs the stability. The pressure difference across the cover layer is dependent on the wave conditions and the permeability of the structure. This is explained in more detail in this section.

The stability of block revetments is not susceptible for the fast flowing water during wave run-up and wave rundown because of its rather smooth surface. The stability is especially jeopardized by pressure gradients on the slope. For practical reasons we focus on the pressure potential (piezometric head) $\phi$ :

$$
\phi=\frac{p}{\rho g}+z
$$


with: $\phi=$ pressure potential $(\mathrm{m}) ; \mathrm{p}=$ pressure $(\mathrm{Pa}), \rho=$ density of water $\left(\mathrm{kg} / \mathrm{m}^{3}\right), \mathrm{g}=$ gravity acceleration $\left(\mathrm{m} / \mathrm{s}^{2}\right)$ and $\mathrm{z}=$ vertical coordinate $(\mathrm{m})$

The pressure potential in the filter underneath the cover layer is a damped representation of the pressure distribution on the slope. This is shown in Figure 10 at the moment of a wave impact. A similar situation occurs just before impact, namely during maximum wave rundown, see Figure 11.

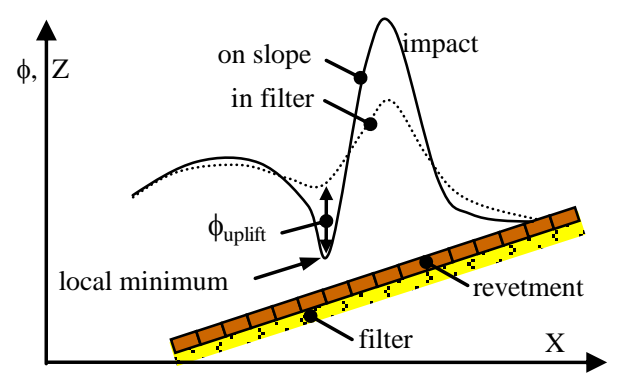

Figure 10, Pressure potential distribution on the slope and in the filter during wave impact (schematised).

A formula for the pressure potential in the filter can be derived on the basis of the mass balance in a small section of the revetment and filter with length $\Delta y$, as shown in Figure 11 (Bezuijen et al 1996). The pressure transmission through the filter is governed by the leakage length $(\Lambda)$ :

$$
\Lambda=\sqrt{\frac{k D b}{k^{\prime}}}
$$

where $\mathrm{k}$ and k' are the permeability of the filter and top layer respectively $(\mathrm{m} / \mathrm{s})$ and $\mathrm{b}$ and $\mathrm{D}$ the thickness of these layers (m). A long leakage length means quite some damping of the pressures in the filter layer compared to the wave pressure on the slope and therefore potentially high uplift pressures.

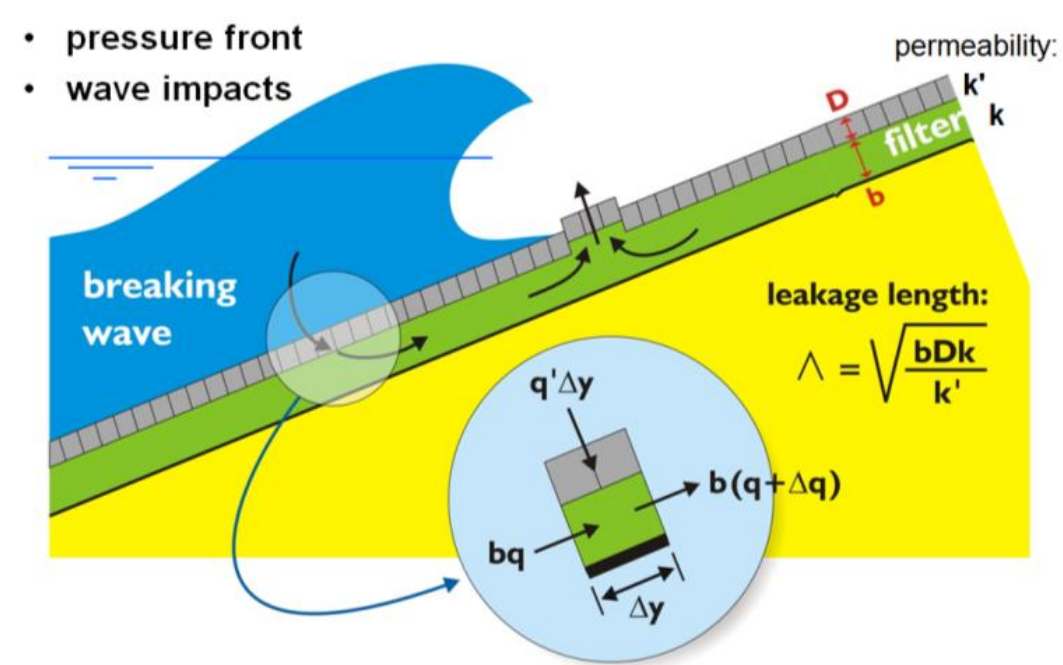

Figure 11, Principle of physical processes leading to uplift pressure (schematised).

The block motion is related to the product of the uplift pressure across the cover layer and the duration of this. This product equals the uplift impulse, which can be held responsible for the block motion. This approach has been checked thoroughly in previous research (e.g. Hofland et al 2005).

'Steentoets' is the present-day calculation tool to design new block revetments and to assess the stability of existing block revetments in the framework of the Dutch law that requires such safety assessment every 12 years. It is based on the leakage length theory described above and also has empirical formulas for:

- Characteristic pressure distribution on the slope during maximum wave run-down (2 types) and wave impacts (3 types)

- Permeability of the cover layer (blocks with joints) and the granular filter layer 
The stability is assessed by comparing the uplift pressure with the block weight and the interaction of the blocks. Especially the contribution of the interaction of the blocks to the strength is difficult to predict. The Delta Flume experiments were mainly focused on determining this aspect by measuring the significant wave height at which damage of the revetment occured.

Up to now Steentoets didn't distinguish between the various types of modern block revetments, because it only distinguished two categories of block revetments, while all modern types fell in one category. By calibrating the calculation tool with the results of the Delta Flume tests, the type-specific stability of each type of block revetment could be included.

\section{TEST SET-UP}

Large-scale tests have been carried out in the Delta Flume to find the stability of the block revetments. The block revetments were installed in a test section on a dike with a slope of 1:3 in the old Delta Flume, see Figure 12. This flume was $220 \mathrm{~m}$ long, $5 \mathrm{~m}$ wide and $7.5 \mathrm{~m}$ deep and can generate waves up to $\mathrm{H}_{\mathrm{m} 0}=1.5 \mathrm{~m}$. The test section with the block revetment was constructed between $+2.0 \mathrm{~m}$ and above $+5.5 \mathrm{~m}$ relative to the flume bottom, with a dummy revetment with a high stability below and above it, up to the crest (see Figure 9). The crest of the dike was at a level of $+8.3 \mathrm{~m}$.

Only Basalton+ was tested in a slightly different test setup in the new Delta Flume, see Figure 13. The new Delta Flume, opened in 2015, is $9.5 \mathrm{~m}$ deep and can generate larger waves. The maximum significant wave height in the new Delta Flume is $2.0 \mathrm{~m}$.

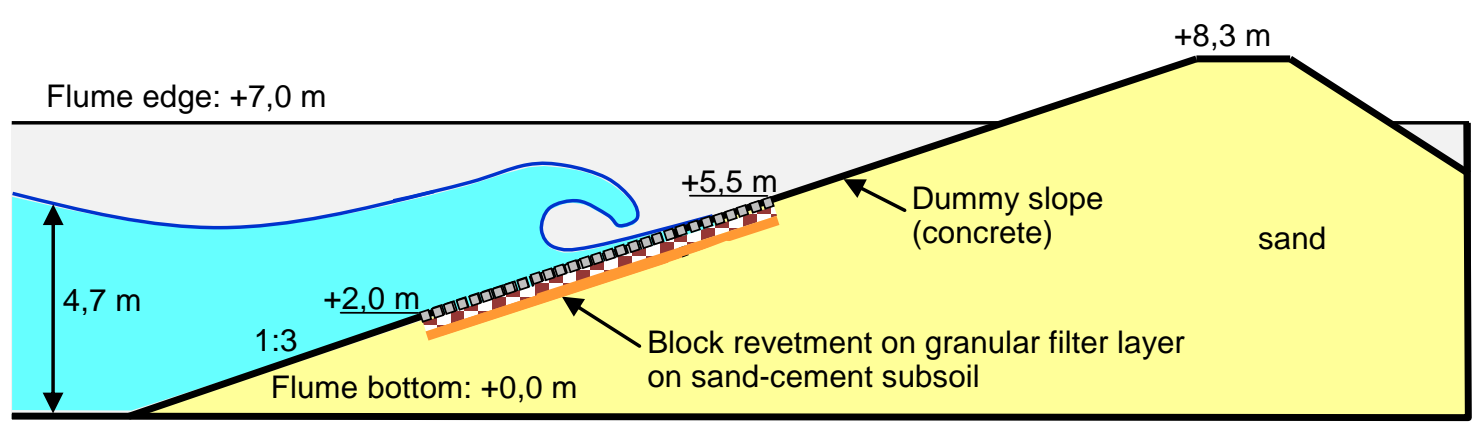

Figure 12, Test setup for measuring the stability of the block revetments (Basalton+ was measured with the test setup in Figure 13)

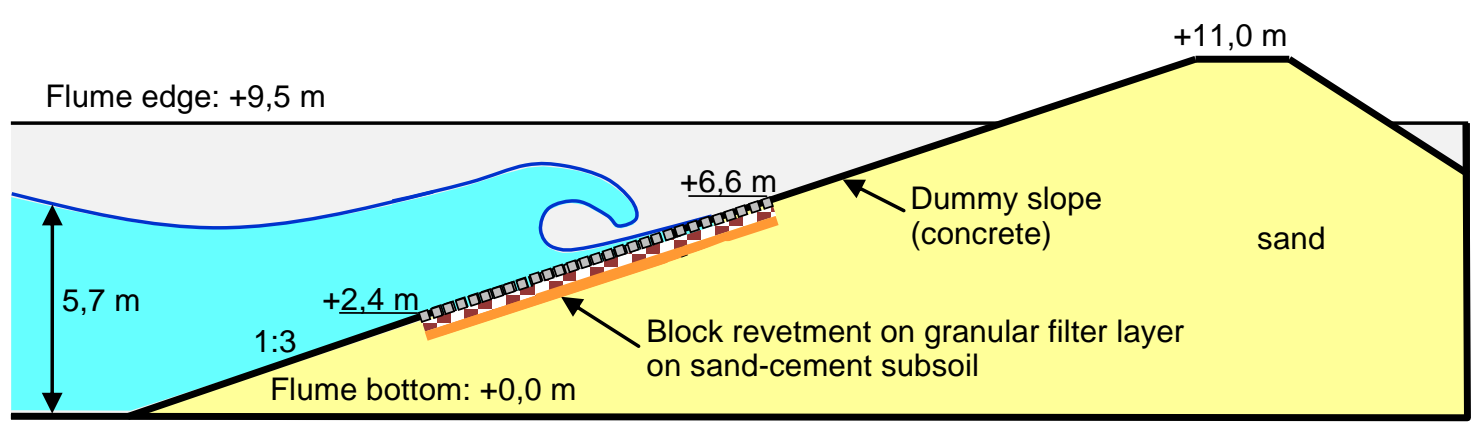

Figure 13, Test setup for measuring the stability of the block revetments in the new Delta Flume

The tests were carried out on scale, because otherwise it was not possible to achieve damage to the revetment within the range of possible wave conditions in the Delta Flume. The scale was 1:2, except for Basalton+, which was tested on scale 1:1.6. This scale is acceptable considering the mentioned scale effects. All dimensions given in this paper are the actual dimensions in the flume.

Table 2 gives detailed information about the dimensions of the blocks, the applied gravel in the joints of the blocks and the granular filter layer underneath. The gravel in the joints turned out to be a very important aspect of the stability of the block revetment. It makes that the blocks have a firm interaction so that an individual block cannot be lifted out of the revetment without also lifting the neighbouring blocks. 


\begin{tabular}{|c|c|c|c|c|c|c|}
\hline \multirow[b]{2}{*}{ Type } & \multicolumn{4}{|c|}{ Cover layer } & \multicolumn{2}{|c|}{ Granular filter } \\
\hline & $\mathrm{D}(\mathrm{mm})$ & $\rho_{c}\left(\mathrm{~kg} / \mathrm{m}^{3}\right)$ & $\begin{array}{c}\Omega \\
(\%)\end{array}$ & $\begin{array}{c}D_{i 15} \\
(\mathrm{~mm})\end{array}$ & b (mm) & $\begin{array}{c}D_{\mathrm{f} 15} \\
(\mathrm{~mm})\end{array}$ \\
\hline Basalton 30 STS & 150 & 2293 & 9.7 & 8.5 & 70 & 11 \\
\hline Basalton+ 30 STS & 179 & 2297 & 9.4 & 5.8 & 79 & 12 \\
\hline Testblok & 150 & 2390 & 8.4 & 4.4 & 73 & 11.5 \\
\hline Hillblock $^{(B)}$ & 200 & 2372 & 8.4 & 5.0 & 70 & 12 \\
\hline RONA $^{(\Theta)}$ ton & 145 & 2112 & 10.0 & 10.4 & 75 & 11 \\
\hline RONA $^{(B)}$ Taille & 151 & 2239 & 7.9 & 8.6 & 70 & 11 \\
\hline Verkalit $^{(B)}$ mgv & 152 & 2355 & 6.5 & - & 49 & 2.8 \\
\hline Verkalit $^{(B)}$ GOR & 151 & 2342 & 6.5 & - & 50 & 2.7 \\
\hline C-Star & 175 & 2346 & 10.3 & 8 & 73 & 11 \\
\hline
\end{tabular}

Table 2, Dimensions of tested revetments and granular filter layers

The following parameters are used in this table:

$\mathrm{D}=$ cover layer thickness $(\mathrm{m})$

$\rho_{\mathrm{c}}=$ density of the concrete of the blocks $\left(\mathrm{kg} / \mathrm{m}^{3}\right)$

$\Omega=$ relative open area between the blocks (relative surface of joints) (-)

$\mathrm{D}_{\mathrm{i} 15}=$ grain size of the granular material in the joints, of which $15 \%$ by weight is smaller $(\mathrm{mm})$

$\mathrm{b}=$ granular filter layer thickness $(\mathrm{m})$

$\mathrm{D}_{\mathrm{f} 15}=$ grain size of the granular material in the filter, of which $15 \%$ by weight is smaller $(\mathrm{mm})$

\section{TEST PROGRAM}

Three series of tests were conducted for each type of block revetment. The first two series consisted of short duration tests of 1000 waves. During these test series the wave height was increased after each test if no damage occurred. In the first test series the wave steepness was $\mathrm{s}_{\mathrm{op}}=\mathrm{H}_{\mathrm{m} 0} /\left(\mathrm{g} /(2 \pi) \mathrm{T}_{\mathrm{p}}{ }^{2}\right)=0.02$ and in the second test series this was 0.04 . The third test series was a long duration test with a maximum duration of 26 hours, or until damage occurred.

A typical test programme is given in Table 3.

\begin{tabular}{|l|c|c|c|c|c|}
\hline Test series & $\mathbf{S}_{\mathrm{op}}(-)$ & $\mathbf{H}_{\mathbf{m} \mathbf{0}}(\mathbf{m})$ & $\mathbf{T}_{\mathbf{p}}(\mathbf{s})$ & $\mathbf{H}_{\mathbf{m o}} /(\mathbf{\Delta} \mathbf{D})$ & Duration $(\mathbf{h})$ \\
\hline \multirow{3}{*}{$\begin{array}{l}\text { 1: low wave steepness, short } \\
\text { duration tests }\end{array}$} & 0.02 & 1.20 & 6.20 & 4.9 & 1.9 \\
\cline { 2 - 6 } & 0.02 & 1.40 & 6.70 & 5.7 & 2.0 \\
\cline { 2 - 6 } & 0.02 & 1.65 & 7.27 & 6.7 & 2.2 \\
\cline { 2 - 6 } & 0.02 & 1.90 & 7.80 & 7.7 & 2.4 \\
\hline \multirow{4}{*}{$\begin{array}{l}\text { 2: normal wave steepness, short } \\
\text { duration tests }\end{array}$} & 0.04 & 1.30 & 4.56 & 5.3 & 1.4 \\
\cline { 2 - 6 } & 0.04 & 1.45 & 4.82 & 5.9 & 1.5 \\
\cline { 2 - 6 } & 0.04 & 1.70 & 5.22 & 6.9 & 1.6 \\
\cline { 2 - 6 } & 0.04 & 1.95 & 5.59 & 7.9 & 1.7 \\
\hline 3: long duration test & 0.04 & 1.40 & 4.74 & 5.7 & 2 \\
\cline { 2 - 6 } & 0.04 & 1.40 & 4.74 & 5.7 & 4 \\
\cline { 2 - 6 } & 0.04 & 1.40 & 4.74 & 5.7 & 8 \\
\cline { 2 - 6 } & 0.04 & 1.40 & 4.74 & 5.7 & 12 \\
\hline
\end{tabular}

Table 3, Typical test program (each test series carried out until damage occurred)

The following parameters have been used in this table:

$\mathrm{s}_{\mathrm{op}}=\mathrm{H}_{\mathrm{mo}} /\left(\mathrm{gT}_{\mathrm{p}}^{2} /(2 \pi)\right)=$ wave steepness (-)

$\mathrm{H}_{\mathrm{m} 0}=$ significant wave height based on the energy density spectrum (m)

$\mathrm{T}_{\mathrm{p}}=$ wave period at the peak of the spectrum $(\mathrm{s})$

$\mathrm{H}_{\mathrm{m} 0} /(\Delta \mathrm{D})=$ stability parameter $(-)$

$\mathrm{D}=$ thickness of the cover layer $(\mathrm{m})$

$\Delta=\left(\rho_{c}-\rho\right) / \rho=$ relative density of the blocks $(-)$

$\rho=$ density of the water $\left(1000 \mathrm{~kg} / \mathrm{m}^{3}\right)$

$\rho_{\mathrm{c}}=$ density of the concrete of the blocks $\left(\mathrm{kg} / \mathrm{m}^{3}\right)$ 


\section{ANALYSIS OF THE TEST RESULTS}

The tests resulted in three values of the significant wave height at damage, one in each test series. For each of these the wave significant height at damage is also calculated with the calculation tool, using an estimate of the interaction of the blocks. Based on these numbers a correction factor is derived that should be included in the calculation tool to achieve that the calculation tool gives the same results as the Delta Flume tests, taking into account a safety margin.

The safety margin is only meant for the less certain aspect of the stability: the interaction between the blocks. For the weight of the blocks no safety margin is necessary, because this can be calculated very accurately.

The safety margin is made dependent on the standard deviation of the three tests. The larger the standard deviation, the larger the safety margin.

To be able to have a safety margin on only the block interaction component of the strength, calculations were made with the calculation tool, assuming no interaction at all. This is regarded as the basic strength with high certainty (green dot in Figure 14). The wave height at damage measured in the Delta Flume is much higher (red dot in Figure 14) and the difference with the calculated stability without interaction is regarded as the contribution of the interaction. A safety margin is introduced for that component of the strength. The strength is quantified with the following parameter:

$$
\frac{H_{m 0}}{\Delta D}
$$

With:

$\mathrm{H}_{\mathrm{m} 0}=$ largest wave height at which no damage occurs (m)

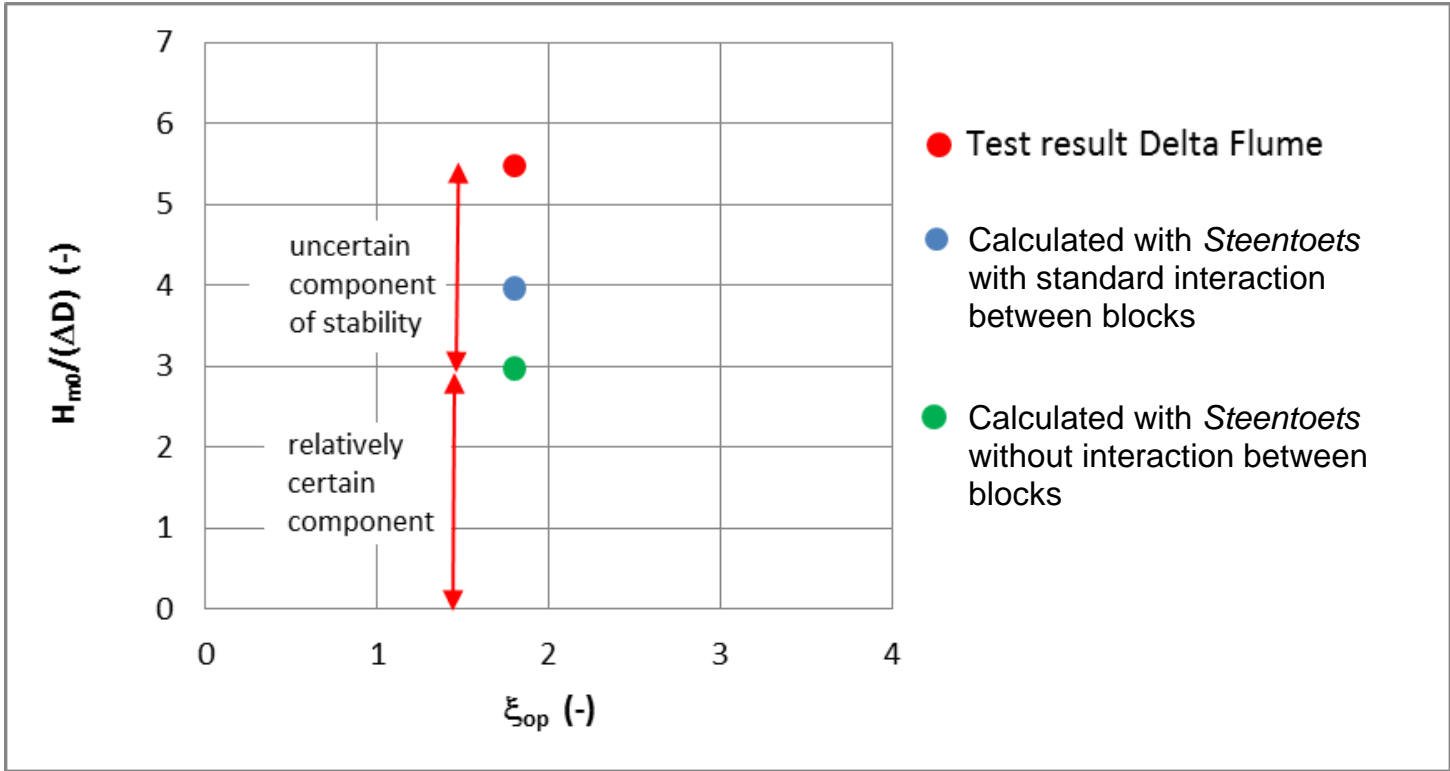

Figure 14, Concept of relatively certain component of stability and uncertain component (interaction between the blocks)

Based on the above principle the following procedure to calculate the correction factor is used:

1. Calculate the required cover layer thickness $\left(D_{\text {calc }}\right)$ with the calculation tool for each test series with a standard estimation of the interaction between the blocks and the wave conditions as measured in the Delta Flume (highest value that did not give damage).

2. For each test series calculate the ratio between the calculated required cover layer thickness Dcalc and the actual block thickness in the Delta Flume: $\mathrm{D}_{\text {calc }} / \mathrm{D}_{\text {flume }}$.

3. Calculate the average value and standard deviation of $D_{\text {calc }} / D_{\text {flume }}$ of the three series: $\mu\left(D_{\text {calc }} / D_{\text {flume }}\right)$ and $\sigma\left(\mathrm{D}_{\text {calc }} / \mathrm{D}_{\text {flume }}\right)$. 
4. Calculate the safety factor $\gamma$, based on the $10 \%$ value in the Student probability distribution: $\gamma=1.1$ $+1.89 \cdot \sigma\left(\mathrm{D}_{\text {calc }} / \mathrm{D}_{\text {flume }}\right)$

5. Calculate the required cover layer thickness $\left(D_{\text {basic }}\right)$ with the calculation tool for each test series with no interaction between the blocks at all, with the wave conditions as measured in the Delta Flume (highest value that did not give damage).

6. Calculate correction factor (stability factor) with the following formula:

$$
f=\frac{\mu\left(D_{\text {calc }} / D_{\text {flume }}\right)-\mu\left(D_{\text {calc }} / D_{\text {basic }}\right)}{\gamma}+\mu\left(D_{\text {calc }} / D_{\text {basic }}\right)
$$

In this way we can achieve that the safety factor is only used on the uncertain part of the strength of the revetment, which is the difference between the results of the flume tests (red dot in Figure 14) and the calculated stability without any interaction between the blocks (green dot in Figure 14).

Note that the parameter $\mathrm{D}$ is in the denominator of the stability parameter $\mathrm{H}_{\mathrm{m} 0} /(\Delta \mathrm{D})$. The formula can also be written as follows, showing that $\mathrm{f}$ is applied on 1/D:

$$
\frac{1}{D_{\text {design }}}=f \frac{1}{D_{\text {calc }}}=\frac{\mu\left(1 / D_{\text {flume }}\right)-\mu\left(1 / D_{\text {basic }}\right)}{\gamma}+\mu\left(1 / D_{\text {basic }}\right)
$$

With $D_{\text {design }}=$ the required cover layer thickness, including the correction factor derived from the present tests $(\mathrm{m})$

The resulting value of the correction factor $f$ has been given in Table 4 and 5 . The value of $\left\{\mathrm{H}_{\mathrm{m} 0} /(\Delta \mathrm{D})\right\}_{\max }$ is the average of the two test series with short duration tests and the average between the test with the largest $H_{\mathrm{m} 0}$ where no damage occurred and the test with the lowest $\mathrm{H}_{\mathrm{m} 0}$ where damage did

\begin{tabular}{|c|c|c|}
\hline type & $\left\{H_{\operatorname{mo}} /(\Delta D)\right\}_{\max }$ & $f$ \\
\hline RONA ${ }^{(B)}$ ton & 9.02 & 1.19 \\
\hline Hillblocks ${ }^{\circledR}$ & $\star *$ & 1.19 \\
\hline Basalton+ & 8.22 & 1.18 \\
\hline C-Star & 7.08 & 1.17 \\
\hline Verkalit $^{(\Theta)} \mathrm{mgv}$ & 7.69 & $0.89^{*}$ \\
\hline Verkalit ${ }^{(\theta)}$ GOR & 7.21 & $0.70^{*}$ \\
\hline
\end{tabular}
occur.

Table 4, Results of the tests for block revetments with excellent performance (*: see text for explanation of performance) ${ }^{* *}$ : not damaged at highest waves in Delta Flume)

\begin{tabular}{|l|c|c|}
\hline type & $\left\{\mathbf{H}_{\mathbf{m 0}} /(\Delta \mathbf{D})\right\}_{\max }$ & $\mathbf{f}$ \\
\hline Basalton & 5.38 & 0.98 \\
\hline RONA ${ }^{(B)}$ Taille & 4.49 & 0.89 \\
\hline Testblok & 3.99 & 0.85 \\
\hline
\end{tabular}

Table 5, Results of the tests for block revetments with disappointing stability

The table shows quite large differences between the various block revetment types regarding the value of $\mathrm{f}$. This means that some of the revetments performed very well because of their very good interaction between the blocks (RONA ${ }^{\circledR}$ ton, Hillblocks ${ }^{\circledR}$, Basalton+, C-Star), leading to high stability under wave attack. Others have a disappointing interaction between the blocks (Basalton, Testblok, RONA $^{\circledR}$ Taille) or failed because of another failure mechanisms. We noticed during the tests that for certain block revetments the gravel in the joints washed out during the wave attack, resulting in a quite poor interaction between the blocks. But also unexpected damage mechanisms occurred, such as during the tests with RONA ${ }^{\circledR}$ Taille. The objective of the shape of the RONA ${ }^{\circledR}$ Taille was such that it also would reduce the wave run-up. The high velocity flow of the wave run-up was hitting onto edges of the blocks, which eventually has led to a jiggling motion of the blocks out of the revetment.

Verkalit $^{\circledR}$ has turned out to be a special case. The blocks have interlocking, which prevents individual blocks to be lifted out of the revetment. But the interlocking is such that adjacent blocks can very easily (with hardly any force) be rotated. The consequence is that any uplift pressure that exceeds the block weight, will lead to deformations of the block revetment. The revetment can be regarded as a heavy blanket on the slope, not able to resist any bending moments in the cover layer. The performance 
in wave attack is however excellent. This is because of the very low leakage length of the system. The permeability of the cover layer compared to the filter layer is such that the leakage length is very low, leading to very low uplift pressures during wave attack. Although the f-factor of this system is quite low, the performance is comparable to the best revetment types with a $\mathrm{f}$ in the range of 1.17 to 1.19.

The gravel in the joins turns out to be a very important aspect of the stability. If the shape of the joints is such that the gravel washes out during wave attack, the interaction between the blocks is decreasing. This has lead to a sudden failure of some revetments at a relatively low wave height.

\section{CONCLUSIONS}

Nine different types of modern block revetments presently on the market in the Netherlands have been tested in the Delta Flume of Deltares on large scale to compare their stability. Each has been tested on a similar dike slope of 1:3 (V:H) under similar circumstances. This has proven to be an excellent way of comparing the stability of these revetments. The best performing blocks are shown to withstand much higher wave conditions as the disappointing blocks, with the same amount of concrete.

The introduction of the correction factor in the calculation method, which now includes the typespecific stability of each block revetment, has stimulated the innovation in this field. Manufacturers now see that it is worthwhile to develop a new type of block revetment to see if they can beat the competitors in the market. The correction factor is included in the new release of the calculation tool.

The gravel in the joints between the blocks contributes substantially to the interaction of the blocks and with this also to the stability of the revetment. The Verkalit ${ }^{\circledR}$ turned out to be a special case. The blocks have an interlocking system, but this doesn't prevent the revetment to deform when uplift pressures exceed the block weight, because the revetment cannot withstand bending moments. But the leakage length of this system is so low, that the uplift pressures are low, giving it a similar good performance as the revetments with a good interaction between the blocks.

\section{References}

Bezuijen, A, and M. Klein Breteler (1996); Design formulas for block revetments, Journal of Waterways, Port, Coastal and Ocean Engineering, November/December 1996

Hofland, B. and M. Klein Breteler (2005); Accuracy of Zsteen during wave impacts (in Dutch); Delft Hydraulics, report H4455, April 2005.

Klein Breteler, M. (2016); Comparison of block revetment stability; summary report (in Dutch); Deltares, report 1208618-006-HYE-0022, 7 July 2016

NEN7024 (Dutch standard), Elements for block revetments, general requirements, ICS 91100.30; 93.160, April 2015

Van Steeg, P., M. Klein Breteler, Y. Provoost (2016); Large-scale physical model tests to determine influence factor of roughness for wave run-up of channel shaped block revetments; Proceedings of the 6th International Conference on the Application of Physical Modelling in Coastal and Port Engineering and Science (Coastlab 2016), Ottawa 